\title{
Zinc and cognitive development
}

\author{
Shinjini Bhatnagar* and Sunita Taneja \\ All India Institute of Medical Sciences, Ansari Nagar, New Delhi-110029, India
}

\begin{abstract}
Cognition is a field of thought processes by which an individual processes information through skills of perception, thinking, memory, learning and attention. Zinc deficiency may affect cognitive development by alterations in attention, activity, neuropsychological behavior and motor development. The exact mechanisms are not clear but it appears that zinc is essential for neurogenesis, neuronal migration, synaptogenesis and its deficiency could interfere with neurotransmission and subsequent neuropsychological behavior. Studies in animals show that zinc deficiency during the time of rapid brain growth, or during the juvenile and adolescent period affects cognitive development by decreasing activity, increasing emotional behavior, impairing memory and the capacity to learn. Evidence from human studies is limited. Low maternal intakes of zinc during pregnancy and lactation were found to be associated with less focused attention in neonates and decreased motor functions at 6 months of age. Zinc supplementation resulted in better motor development and more playfulness in low birth weight infants and increased vigorous and functional activity in infants and toddlers. In older school going children the data is controversial but there is some evidence of improved neuropsychological functions with zinc supplementation. Additional research is required to determine the exact biological mechanisms, the critical periods, the threshold of severity and the long-term effects of zinc deprivation on cognitive development.
\end{abstract}

\section{Zinc: Cognition}

\section{Cognitive development}

Cognition is a complex construct and consists of a field of thought processes by which an individual registers, encodes, selects, maintains, transforms, stores and retrieves information. This would extend to include visual and somatosensory perception, thinking, memory, and learning. Memory helps to learn, retain and reproduce information. Another important aspect is attention; an integrated process by which the individual, from the time of infancy focuses on information that is essential for its growth and development (Ruff \& Rauthbart, 1996). It includes a readiness to respond and an intact capacity to focus on one thing resisting other distracting stimuli.

In the first year of life, the infant learns to construct mental structures, which is dependent on perceptions and body movements. It further develops its attention skills by exploring and concentrating on the novel aspects of its environment and extends it to focus on testing and organizing the information through the pre-school years. Activity and motor skills form an integral part of developing the attention system by increasing the responsiveness to the environment. A lethargic child with delayed motor activity would have fewer opportunities to explore and concentrate on specific objects or events. Activity would be directly related to motor activities at that particular age.
Cognitive development continues as a period of concrete operations through school years as skills like thought, memory and language develop (Piaget, 1997). During this period multiple stimuli are appreciated simultaneously and attention abilities increase with greater learning and memory. Full adult intelligence and hypothetical thinking evolve during adolescence.

Assessment of cognitive development would include evaluation of perception, thought, attention, memory, language and activity.

\section{Biological mechanisms of zinc deprivation on cognitive development}

Zinc has a critical role in the function of several structural, regulatory and catalytic proteins (Fierke, 2000; Hambidge, 2000). It is present in the brain bound to proteins and is important for its structure and function (Pfeiffer \& Braverman, 1997; Sandstead, 1986). Prompted by early reports of birth defects in the offspring of zinc deficient rats (Hurley \& Shrader, 1972; Dreosti \& Smith, 1983), extensive work has been done on animals to examine the role of zinc deficiency on brain function and cognitive development. The exact mechanisms are not clear but its presence in high concentrations in the synaptic vesicles of the special 'zinc containing' neurons in the forebrain

\footnotetext{
* Corresponding author: Dr Shinjini Bhatnagar, fax +91 11 6862663, email shinjini_bhatnagar@rediffmail.com
} 
(Hesse, 1979; Howell et al. 1984; Frederickson \& Danscher, 1990; Frederickson et al. 2000) together with its function in biochemical processes like myelination and release of neurotransmitters like $\gamma$-amino butyric acid [GABA] (Ben-Ari \& Cherubini, 1991) and glutamate, indicates that it may be a key modulator of neuronal excitability. There is also some evidence to suggest that zinc deficiency results in lowered levels of long $\omega-3$ and $\omega$ 6 chains possibly causing impaired fatty acid metabolism in the neurons (Wauben et al. 1999). Moreover, it seems to be important for neurogenesis, neuronal migration and synaptogenesis and its deficiency could interfere with neurotransmission and subsequent neurophysiological development (Dvergsten, 1984; Colvin et al. 2000; Fredrickson et al. 2000). In addition, zinc is involved in the metabolism of thyroid hormones, receptor function and transport of other hormones that could influence the central nervous system (Morley et al. 1980).

\section{Animal studies}

Rats have been used to study the effects of zinc deprivation during the prenatal period and infancy while the rhesus monkey model is well suited for evaluating deficiency in childhood and adolescence. Rats have a brief 2-week period between weaning and puberty whereas in monkeys it is 3 years. Therefore, the period from 18 to 45 months in monkeys is approximately equivalent to 6-16 years in humans. Furthermore, like humans they have an adolescent growth spurt during which micronutrient deficiency could be induced.

\section{Critical period studies}

Animal research has shown that severe maternal zinc deficiency in early pregnancy, a period of fetal organogenesis, results in impaired implantation, fetal resorption, abortions and fetal brain malformations (Hurley \& Shrader, 1972; Dreosti \& Smith, 1983).

Studies with a critical period design evaluated the effects of maternal zinc deprivation during periods of rapid fetal and infant brain growth. Zinc deficient diets were given to pregnant animals during the last third of gestation (14-20 days) or during lactation, a period which would not affect organogenesis but would be critical for brain growth. The experimental treatment was stopped after a certain period, the animals were rehabilitated with a normal zinc diet and the impact of zinc deprivation during periods of brain growth was examined on activity, attention and behavior later in the offspring after they had achieved sexual maturation. The control group was fed a zinc adequate diet ad libitum. Since the effects of zinc deprivation could be ascribed to reduced food intake and not just deficiency of zinc, another group of controls who were pair-fed with the same amount of food consumed by the zinc deprived group was included. These studies showed that nutritional insult during the critical period of cerebral growth did not get reversed with subsequent ad libitum feeding. The rehabilitated adult offspring exhibited poor performance of shock induced learning tasks (Lokken et al. 1973; Halas \& Sandstead, 1975) and an enhanced shock motivated aggression (Halas et al. 1977). The investigators attributed this behavior to increased emotionality and heightened susceptibility to stress.

Similarly adults rehabilitated after severe lactational zinc deprivation (0-20 days postnatal) showed poor performance of tasks designed to test long-term, short-term and working memory as compared to the controls (Halas et al. $1979 ; 1980 ; 1983)$. When mild to moderate zinc deficiency was induced from birth to weaning (0-20 days postnatal) by zinc deprivation of nursing animals, the rate of brain protein synthesis and the total brain lipids were found to be decreased in the pups. These animals displayed inferior learning and poor working memory following nutritional rehabilitation with zinc after weaning (Sandstead et al. 1975; Halas et al. 1980; Halas \& Sandstead, 1982; Dreosti \& Smith, 1983)

\section{Concurrent period studies}

Studies with a concurrent period design studied the effect on behavior and neuropsychological development of concurrently produced zinc deficiency in monkeys.

Severe zinc deprivation $(<1 \mu \mathrm{g}$ of $\mathrm{Zn}$ per $\mathrm{g}$ diet) in nursing (before weaning) or juvenile (after weaning) monkeys resulted in changes in emotional behavior and cognitive function deficits respectively. The severely zinc deprived monkeys who had not been weaned were difficult to separate from their over protective mothers while the juvenile monkeys were unable to retain previously learned tasks and had difficulties in learning new problems (Strobel \& Sandstead, 1984).

In a crossover trial, concurrent moderate zinc deficiency was induced over a short period of 15 weeks in juvenile monkeys (20-24 months) by giving a $2 \mu \mathrm{g}$ of $\mathrm{Zn}$ per g diet, thus simulating zinc deficiency in childhood. The zinc deprivation period was compared with periods of zinc adequate ( $50 \mu$ of $\mathrm{Zn}$ per $\mathrm{g}$ ) diet that either preceded or followed it in two sub-groups. Spontaneous motor activity was decreased and performance on tasks of visual attention (assessed by continuous performance task) were inadequate during the zinc-deprived period (Table 1). Short-term memory tasks (delayed spatial alteration) were also affected in these animals.

Effects of long-term zinc deprivation in female monkeys (18-33 months of age) fed on a moderately zinc deficient diet $(2 \mu \mathrm{g}$ of $\mathrm{Zn}$ per $\mathrm{g}$ diet) starting from the pre-puberty period and given through puberty were compared with controls (those given $50 \mu \mathrm{g}$ of zinc per g diet) (Golub et al. 1996). The zinc deprived group showed progressive decline in daytime activity and attention performance (measured by the continuous performance task). These differences were noted before the actual decline in growth spurt had started and the plasma zinc concentrations were reduced indicating the onset of zinc deficiency. The findings of this study suggest that the zinc deprived adolescents maybe more susceptible to behavioral changes before the onset of growth retardation.

In a differently designed series of animal studies Golub et al. $(1984 ; 1985 ; 1988 ; 1990 ; 1994)$ examined cognitive functions at different stages of sexual maturation after producing continuous marginal zinc deprivation during the 
Table 1.

1. Critical period studies: (Lokken et al. 1973; Halas \& Sandstead, 1975; Halas et al. 1977; 1979; 1980; Halas \& Sandstead, 1982) Impact of limited period zinc deprivation during periods of brain growth on offspring behavior after they had become adults

\begin{tabular}{|c|c|c|c|}
\hline \multirow[b]{2}{*}{ Species } & \multicolumn{2}{|c|}{ Deprivation } & \multirow[b]{2}{*}{ Outcome } \\
\hline & Extent & Time & \\
\hline $\begin{array}{l}\text { Rats } \\
\text { Rats } \\
\text { Rats }\end{array}$ & $\begin{array}{l}\text { Severe } \\
\text { Severe } \\
\text { Mild to moderate }\end{array}$ & $\begin{array}{l}14-20 \text { days of gestation } \\
0-21 \text { days postnatal } \\
0-21 \text { days postnatal }\end{array}$ & $\begin{array}{l}\text { Poor avoidance response to shock, increased aggression } \\
\text { Poor memory } \\
\text { Inferior learning }\end{array}$ \\
\hline
\end{tabular}

2. Concurrent period studies: (Golub et al. 1994; 1995; Strobel \& Sandstead, 1984)

Effects of short-term and chronic zinc deprivation on young monkeys (zinc-deprived $v$. zinc-adequate diet periods)

\begin{tabular}{llll}
\hline Monkeys & $\begin{array}{l}\text { Moderate } \\
\text { for } 15 \mathrm{wk}\end{array}$ & $\begin{array}{l}\text { Juvenile } \\
(20-24 \mathrm{mo})\end{array}$ & $\begin{array}{l}\text { Decrease in spontaneous motor activity } \\
\text { Decrease in performance on tasks of visual attention and } \\
\text { short-term memory } \\
\text { Decrease in day-time activity }\end{array}$ \\
Monkeys & $\begin{array}{l}\text { Moderate } \\
\text { through puberty }\end{array}$ & $\begin{array}{l}\text { Juvenile } \\
(18-33 \mathrm{mo})\end{array}$ & $\begin{array}{l}\text { Decrease in attention performance } \\
\text { Difficulty in separating from mothers }\end{array}$ \\
Monkeys & $\begin{array}{l}\text { Severe } \\
\text { Monkeys }\end{array}$ & $\begin{array}{l}\text { Nursing } \\
\text { Juvenile }\end{array}$ & Impaired learning
\end{tabular}

3. Behavior assessment of zinc deprived monkeys during development: (Golub et al. 1984; 1985; 1988; 1990; 1994)

Pregnant mothers fed marginally zinc deficient diet from conception and the offspring fed the same diet after weaning

\begin{tabular}{ll}
\hline Age at evaluation & Outcome \\
\hline Neonates & Lower postural muscle tone \\
$1-12$ months & Less activity, less exploration \\
$30-42$ months (adolescence) & Impaired learning and memory \\
\hline
\end{tabular}

period of rapid brain growth and then concurrently until adolescence. This experiment best simulates a situation that would be commonly seen in malnourished humans. The pregnant monkeys were fed a marginally zinc deficient diet from conception and the offspring were fed the same diet after weaning. The behavior assessment done at several stages of sexual maturation (infant, juvenile, and adolescent) showed general hypoactivity and reduced responses to the environment in young offspring. Effects on cognitive tasks like visual discrimination, learning and memory were more marked in the zinc-deprived adolescents (Table 1).

\section{Human studies}

\section{Observational studies}

Observational studies in humans to examine the association of maternal zinc nutriture on the fetus and neonates are very few (Table 2).

Micronutrient intake including that of bioavailable zinc of Egyptian mothers during the last 6 months of gestation was a significant positive predictor of newborns' habituation behavior assessed by the Brazelton Neonatal Behavior Assessment Scale (Brazelton, 1984) administered within 7 days of birth (Kirksey et al. 1991). More rapid habituation is interpreted as having more focused attention and is a good measure of the infants' early ability to process information. It is also said to predict a variety of cognitive indices in the pre-school period. Motor development evaluated by the Bayley's Scale of Infant Development (Bayley, 1969) applied on these infants at 6 months was negatively related to maternal intakes of plant zinc, phytates and fibre (Kirksey et al. 1994). The results of these observational studies should be interpreted with caution as they may be confounded by deficiency of other micronutrients.

\section{Zinc supplementation studies}

Because of a lack of definitive indicators for assessing zinc deficiency a causal association between zinc deficiency and development may be best inferred from supplementation trials.

Fetal heart rate [FHR] accelerations and increased heart rate variability observed with fetal movements and more vigorous fetal activity are an index of fetal well-being and reflect in utero development of different components of the nervous system (DiPietro et al. 1996a; DiPietro et al. $1996 b)$. Furthermore, fetal neurobehavior at 36 weeks of gestation may predict subsequent infant temperament (DiPetro et al. 1996c). Merialdi et al. (1999) examined FHR and movement patterns at 32 and 36 weeks gestation in 55 fetuses whose mothers were randomly assigned to daily iron and folate supplementation with or without $15 \mathrm{mg}$ of zinc through pregnancy (started at 10-24 weeks of gestation and continued until one week postpartum). All FHR recordings were divided into 3-minute epochs and each epoch was analyzed separately. The fetuses of zinc supplemented mothers had an increased fetal heart range (difference between the highest and the lowest values of the FHR), less minimal variability ( $<$ six beats per minute) and increased number of accelerations (increase in FHR above the basal ten beats per minute lasting for at least 15 seconds) than the fetuses of mothers not supplemented with 
Table 2. Summary of observation and zinc supplementation studies in humans on cognitive development

\begin{tabular}{|c|c|c|}
\hline Study, no. \& age of subjects & Dose and duration of zinc & Outcome in the zinc group \\
\hline $\begin{array}{l}\text { Observation studies } \\
\text { Kirksey et al. 1991; } 1994 \\
50 \text { women }\end{array}$ & Zinc nutriture in last 6 months of pregnancy \& first 6 mo of lactation. & $\begin{array}{l}\text { Quicker habituation (Brazelton Neonatal Assessment Scale) in neonates. } \\
\text { Low scores on Bayley's Motor Development Scale at } 6 \text { months with high } \\
\text { intakes of phytates and fibre }\end{array}$ \\
\hline $\begin{array}{l}\text { Randomized controlled studies } \\
\text { Merialdi et al. } 1999 \\
55 \text { fetus' }\end{array}$ & $\begin{array}{l}15 \mathrm{mg} \text { zinc/day } \\
\text { Through pregnancy (10-24 wk gestation }-1 \text { wk postpartum) }\end{array}$ & $\begin{array}{l}\text { Increased fetal heart range, number of FHR accelerations, minimal FHR } \\
\text { variability \& more vigorous fetal movements }\end{array}$ \\
\hline $\begin{array}{l}\text { Friel et al. } 1993 \\
50 \text { neonates, }<1500 \mathrm{~g}(29 \pm 3 \mathrm{wk})\end{array}$ & $11 \mathrm{mg} \mathrm{zinc} / \mathrm{l}$ of formula $v .6 .7 \mathrm{mg}$ zinc/l of zinc; $6 \mathrm{mo}$ & Higher loco-motor development score (Griffiths Sub Scales) \\
\hline $\begin{array}{l}\text { Ashworth et al. } 1998 \\
1500-2499 \mathrm{~g} \text {, term, } 134 \text { neonates }\end{array}$ & $1 \mathrm{mg}$ zinc/d $v$. placebo & $\begin{array}{l}\text { No difference in mental, psychomotor development or behavior. } \\
\text { Highest ratings on all Behavior Scales (Bayley et al and Wolke et al) at } \\
12 \text { months }\end{array}$ \\
\hline 71 neonates & $\begin{array}{l}5 \mathrm{mg} \text { of zinc/day with no concurrent controls } \\
8 \text { weeks }\end{array}$ & \\
\hline $\begin{array}{l}\text { Sazawal et al. } 1996 \\
93 \text { subjects, } 12-23 \text { months }\end{array}$ & $10 \mathrm{mg}$ zinc/day; 1 month & $\begin{array}{l}\text { Spent } 72 \% \text { more time performing higher movement activities. Greater effect } \\
\text { in boys. }\end{array}$ \\
\hline $\begin{array}{l}\text { Bentley et al. } 1997 \\
85 \text { subjects, } 6-9 \text { months }\end{array}$ & $10 \mathrm{mg}$ zinc/day; 7 months & More time in sitting, playing than lying; less time in crying. \\
\hline $\begin{array}{l}\text { Sandstead et al. } 1998 \\
740 \text { subjects, } 6-9 \text { years }\end{array}$ & $\begin{array}{l}20 \mathrm{mg} \text { zinc/day } v .20 \mathrm{mg} \text { of zinc and other micronutrients } v \text {. } \\
\text { other micronutrients alone; } 10 \text { weeks }\end{array}$ & $\begin{array}{l}\text { Significant improvement in fine and gross motor skills, sustained attention and } \\
\text { capacity for concept formation and abstract reasoning (Cognition } \\
\text { Psychomotor Assessment System) in the group receiving zinc and other } \\
\text { micronutrients }\end{array}$ \\
\hline $\begin{array}{l}\text { Cavan et al. } 1993 \\
162 \text { subjects, } 7-8 \text { years }\end{array}$ & $10 \mathrm{mg}$ zinc/day; 25 weeks & No difference on mental concentration or short term memory \\
\hline $\begin{array}{l}\text { Gibson et al. } 1989 \\
60 \text { subjects, } 5-7 \text { years }\end{array}$ & $10 \mathrm{mg}$ zinc/day; $12 \mathrm{mo}$ & No difference in average attention span scores \\
\hline
\end{tabular}


zinc. They also had more vigorous in utero activity as observed by increased larger movements. In addition, the differences associated with zinc supplementation increased with advancing gestational period. Although, this study supports some role of prenatal zinc supplementation in improving in utero neurobehaviour, the data needs to be interpreted with caution because of the small sample size and certain methodological limitations of the study. Further, the indices used for testing need to be validated (Table 2).

It is suggested that inadequate zinc intake may lead to poor developmental outcomes in very low birth weight neonates. They are likely to be deficient in zinc because of reduced zinc stores at birth. Friel et al. (1993) evaluated the effect of zinc supplementation in fifty-two infants (fortyone appropriate size for age and eleven small for gestational age) with birth weight $<1500$ g. The neonates were randomized at discharge to receive either a regular term formula supplemented to provide $11 \mathrm{mg} / \mathrm{L}$ of zinc or the same formula without additional zinc (final concentration of $6.7 \mathrm{mg}$ zinc/L) for a period of 6 months. The supplemented group had higher plasma zinc levels at 1 and 3 months but not after the supplementation was stopped. While there were no significant differences in the overall developmental score on the Griffiths scale (Griffiths, 1979) applied at every 3 months from 3 to 12 months, the maximum locomotor development scores on the sub-scales were higher in the supplemented group (Table 2).

A study from Brazil (Ashworth et al. 1998) intended to examine the effect of supplementing $5 \mathrm{mg}$ of zinc daily (except on Sundays) for a period of 8 weeks starting from birth, to term infants weighing 1500-2499 g on mental and behavioural development as compared to a placebo. After the first 13 months of the study, it was discovered that because of a mistake in the zinc formulation 66 babies had received $1 \mathrm{mg}$ of zinc/day instead of $5 \mathrm{mg} /$ day. The design was modified and another cohort of 71 low birth weight, term neonates were recruited over the next 7 months and were given $5 \mathrm{mg}$ of zinc daily. There were no concurrent controls for this period. Mental and psychomotor development assessed by the Bayley Scales of Infant Development (Bayley, 1969) at 6 and 12 months did not show any significant differences between the three groups. At 12 months the infants' behavior was rated on five scales adapted from the rating scales of Bayley (1993) and Wolke et al. (1990). While there were no differences between the groups receiving either $1 \mathrm{mg}$ zinc per day or a placebo the subjects supplemented with $5 \mathrm{mg}$ zinc per day had the highest scores on all ratings. These infants were more responsive to the environment than the others and were less inhibited or fearful. However, since this group was not randomly allocated these results would compare with those of an observational study (Table 2).

Two trials, one in India and the other in Guatemala, studied the association between zinc deprivation and activity in malnourished children. Reduced activity inhibits exploration in children, which may contribute directly to diminished cognitive development. The study in India (Sazawal et al. 1996) found that children randomized to receive $10 \mathrm{mg} /$ day of zinc gluconate in addition to the vitamins A, B1, B2, B6, D3, E and niacinamide spent $72 \%$ more time performing high movement activities like running. The effects were greater in boys and this could be because of extra zinc requirement in boys. The control group received a mixture of vitamins alone. Among the zinc supplemented group, the activity rating was $12 \%$ and $8 \%$ higher by a previously validated children's Activity Rating and the energy expenditure score (estimated energy cost of each category of activity) respectively.

Bentley et al. (1997) evaluated the effect of $10 \mathrm{mg}$ of oral zinc given daily for 7 months in a randomized double blind placebo controlled study on the activity patterns of eighty-five Guatemalan infants. These children were younger and better nourished than the Indian children. The infant activity was assessed by the time sampling observation method at baseline and then at 3 and 7 months follow-up. The zinc-supplemented group was found to be sitting up more frequently than lying and playing more at 7 months of follow-up. These two studies suggest that zinc supplementation is associated with more vigorous and functional activity respectively. The exact relation between activity and cognitive development it is not clear and is possibly an intermediate step in the development of motor skills and improved cognitive performance.

Although data on zinc supplementation in school going children is limited there is some evidence that zinc status influences neuropsychological behavior (Sandstead et al. 1998). Preparations of zinc with or without other micronutrients or other micronutrients alone were administered double blind 6 days/week for 10 weeks to school going children aged 6-9 years (Table 2). The neuropsychological performance was tested by the CognitionPsychomotor Assessment System - Revised (CPAS - R) developed by JG Penland (Penland et al. 1997). The testing was done over 50 minutes and CPAS software automated the scoring of the neuropsychological tasks. Visual motor tracking and finger tapping assessed eyehand co-ordination and fine and gross motor skills respectively. Continuous performance task measured sustained attention while the oddity task assessed concept formation and abstract reasoning. Treatment with zinc and micronutrients was associated with significant improvement than with micronutrients alone in the following tasks; number of taps on a single key, percentage of time on the target during circular tracking, percentage of correct choices during a continuous vigilance task and the number of trials required to identify correct shapes. However, two earlier double blind placebo controlled studies conducted in the same age group did not report any beneficial effects of zinc supplementation. In Guatemala (Cavan et al. 1993), zinc supplementation of $10 \mathrm{mg} /$ day given for 25 weeks did not improve mental concentration or short-term memory in low income school going children. Similarly, there was no difference in average attention span scores measured on the Detroit Tests of Learning Aptitude (Hammill, 1985) in the low to middle income Canadian children supplemented with $10 \mathrm{mg}$ zinc/day for 12 weeks as compared to the placebo group (Gibson et al. 1989) (Table 2). The improvement in neuropsychological performance in the study by Sandstead et al. (1998) could be due to the correction of other latent micronutrient deficiencies which if present may not 
allow the full beneficial effects of zinc supplementation to manifest themselves.

\section{Discussion}

In sum, there is convincing evidence from animal research that zinc deficiency affects cognitive development by decreasing activity, increasing emotional behavior and impairing memory and the capacity to learn.

It may not always be possible to extrapolate findings from animal research to humans. In animals isolated zinc deficiency can be induced and consistent levels can be maintained over a defined period of time allowing evaluation of the direct causal relationship between zinc deficiency and cognitive functions under optimal conditions. In humans direct causal inferences may be limited by the presence of other deficiencies existing for an indeterminate period of time. As behavior is more complicated in humans, use of animal models may underestimate the effects of nutritional deficiencies. Furthermore, the rates of neuronal and biochemical development differ in humans.

Studies in humans have shown that low maternal zinc intakes are associated with less focused attention in neonates and poor motor activity in the infant at 6 months of age. Zinc supplementation trials have resulted in alteration in fetal neurobehavior, better motor development in very low birth weight infants, more vigorous and functional activity in malnourished infants and toddlers and improved neuropsychological functions in school age children.

Zinc deficiency affects cognitive development by alterations in attention, activity, other features of neuropsychological behavior and motor development. These effects vary by age and may be influenced by the care giving environment particularly the behaviour of the mother and the social context (Black, 1998). The different neuropsychological performances should be assessed with respect to the development expected for that age as in infants and pre-school children, measures of attention span and activity are influenced by motor development for that age while concept formation, development of abstract reasoning, visual perception and short-term memory are more critical for school going children.

Zinc is essential for brain structure and function but to understand the association between zinc and cognitve development it is important to determine the period most affected by zinc deficiency. It appears from animal studies that periods of brain growth and pre-adolescent growth spurt are most sensitive, however there is only limited data available from human studies. In addition, the threshold of severity for zinc deficiency that would influence cognitive performance is essential and would have major implications in developing country settings where mild to moderate zinc deficiency is common.

There is presently no data to show the long-term developmental importance of different activity patterns observed with zinc supplementation. It would be interesting to investigate if the changes in cognitive performance produced by zinc deprivation are irreversible.

More research is needed to examine the biological mechanisms that explain the role of zinc in cognitive development. Zinc deficiency exists as part of overall malnutrition and in combination with other micronutrients. Additional studies are required to study effects of zinc supplementation on cognitive development in combination with other nutrients including micronutrients and to analyze the effects of zinc deprivation independent of moderators like the social and the care giving environment.

\section{References}

Ashworth A, Morris SS, Lira PIC \& MC Gregor SMG (1998) Zinc supplementation mental development and behaviour in low birth weight term infants in northeast Brazil. European Journal of Clinical Nutrition 52, 223-227.

Bayley N (1969) Bayley Scales of Infant Development. New York: The Psychological Corporation.

Bayley N (1993) Bayley Scales of Infant Development. London: The Psychological Corporation, Harcort Brace \& Co.

Bentley ME, Caulfield LE, Ram M, Santizo MC, Hurtado E, Rivera JA, Ruel MT \& Brown KH (1997) Zinc supplementation affects the activity patterns of rural Guatemalan infants. Journal of Nutrition 127, 1333-1338.

Ben-Ari Y \& Cherubini E (1991) Zinc and GABA in developing brain. Nature 353, 220.

Black MM (1998) Zinc deficiency and child development. American Journal of Clinical Nutrition 68 (suppl.), 464S-469S.

Brazelton TB (1984) Neonatal Behavior Assessment Scale. Second edition. Philadelphia: JB Lippincott, Spastics International Medical Publications.

Cavan KR, Gibson RS, Grazioso CF, Isalgue MA, Ruz M \& Solomons NW (1993) Growth and body composition of periurban Guatemalan children in relation to zinc status; a longitudinal zinc intervention trial. American Journal of Clinical Nutrition 57, 344-352.

Colvin RA, Davis N, Nipper W \& Carter PA (2000) Zinc transport in the brain: routes of zinc influx and efflux in neurons. Journal of Nutrition 130, 1484S-1487S.

Dipietro JA, Hodgson DM, Costigan KA, Hilton SC \& Johnson TR (1996a) Development of fetal movements - fetal heart rate coupling from 20 weeks through term. Early Human Development 44, 139-151.

Dipietro JA, Hodgson DM, Costigan KA \& Johnson TRB (1996b) Fetal neurobehavioral development. Child Development 67, 2553-2557.

Dipietro JA, Hodgson DM, Costigan KA \& Johnson TRB (1996c) Fetal antecedents of infant temperament. 67, 2568-2583.

Dreosti IE \& Smith RM (1983) Neurobiology of the Trace Elements 1, Trace Elements Neurobiology and Deficiencies, pp. 135-162. Clifton, NJ: Humana Press.

Dvergsten C (1984) Retarded synaptogenesis and differentiation of cerebellar neurons in zinc -deficient rats. In The Neurobiology of Zinc, Part B: Deficiency, Toxicity and Pathology, vol. 11, pp. 17-31 [C Fredericksen, G Howell and E Kasarkis, editors]. New York, NY: Alan R. Liss.

Fierke C (2000) Function and mechanism of zinc. Journal of Nutrition 130, 1437S-1446S.

Fredericksen CJ \& Danscher G (1990) Zinc containing neurons in the hippocampus and related CNS structures. Progress in Brain Research 83, 71-84

Fredericksen CJ, Suh SW, Silva D, Frederickson CJ \& Thompson RB (2000) Importance of zinc in the central nervous system the zinc containing neuron. Journal of Nutrition 130, 1471S-1483S.

Friel JK, Andrews WL, Mathew DJ, Long DR, Cornel AM, McKim MCD \& Zerbe GO (1993) Zinc supplementation in 
very low birth weight infants. Journal of Pediatric Gastroenterology and Nutrition 1, 97-104.

Gibson RS, Vanderkooy PDS, Mac Donald AC, Goldman A, Ryan BA \& Berry M (1989) A growth limiting, mild zinc deficiency syndrome in some Southern Ontario boys with low height percentiles. American Journal of Clinical Nutrition 49, 1266-1273.

Golub MS, Keen CL, Gershwin ME \& Hendrickx AG (1995) Developmental zinc deficiency and behavior. Journal of Nutrition 125, 2263S-2271S.

Golub MS, Takeuchi PT, Keen CL, Gershwin ME, Hendricke AG \& Lonnerdal B (1994) Modulation of behavioral performance of prepubertal monkeys by moderate dietary zinc deprivation. American Journal of Clinical Nutrition 60, 238-243.

Golub MS, Keen CL, Herdrickx AG \& Gershwin ME (1990) Food preferences of young Rhesus monkeys fed marginally zinc deficient diets. Primates 32, 49-59.

Golub MS, Gershwin ME, Hurley LS \& Hendrickx AG (1988) Studies of marginal zinc deprivation in rhesus monkeys VIII. Effects on early adolescence. American Journal of Clinical Nutrition 47, 1046-1051.

Golub MS, Gershwin ME, Hurley LS \& Saito WY (1985) Studies of marginal zinc deprivation in rhesus monkeys VII. Infant behavior. American Journal of Clinical Nutrition 42, 12291239.

Golub MS, Gershwin ME, Hurley LS, Sation WY \& Hendrickx AG (1984) Studies of marginal zinc deprivation in rhesus monkeys IV. Growth of infants in the first year. American Journal of Clinical Nutrition 40, 1192-1202.

Golub MS, Takeuchi PT, Keen CL, Hendrickx AG \& Gershwin EM (1996) Activity and attention in zinc deprived adolescent monkeys. American Journal of Clinical Nutrition 64, 905-915.

Griffiths R (1979) The abilities of babies. A study in mental measurement. Amersham, England: Eden House.

Halas ES \& Sandstead HH (1975) Some effects of pre-natal zinc deficiency on behavior of the adult rat. Pediatric Research 9 , 94-97.

Halas ES, Reynolds GM \& Sandstead HH (1977) Intra-uterine nutrition and its effects on aggression. Physiology and Behavior 19, 653-661.

Halas ES, Heinrich MD \& Sandstead HH (1979) Long term memory deficits in adult rats due to postnatal malnutrition. Physiology and Behavior 22, 991-997.

Halas ES, Burger PA \& Sandstead HH (1980) Food motivation of rehabilitated malnourished rats implications for learning studies. Animal Learn Behavior 8, 152-158.

Halas ES \& Sandstead SS (1982) Short term memory (STM) deficits due to mild zinc deficiency during gestation and lactation: a reffirmation. Federation Proceedings 41, 781 (abs).

Halas ES, Eberhardt MJ, Diers MA \& Sandstead SS (1983) Learning and memory impairment in adult rats due to severe zinc deficiency during lactation. Physiology and Behaviour 30, 371-381.

Hambidge M (2000) Human zinc deficiency. Journal of Nutrition 130, 1344S-1349S.

Hammill DD (1985) Detroit tests of learning aptitude. Austin: TX: Proed.

Hesse GW (1979) Chronic zinc deficiency alters neuronal function of hippocampal mossy fibers. Science 205, 10051007.

Howell GA, Welch MG \& Frederickson CJ (1984) Stimulation induced uptake and release of zinc in hippocampal slices. Nature London 308, 736-738.

Hurley LS \& Shrader RE (1972) Congenital malformations of the nervous system in zinc deficient rats. In Neurobiology of the Trace Metals Zinc and Copper, pp. 51-60 [CC Pfeiffer, editor]. New York, NY: Academic Press.

Kirksey A, Rahmanifar A, Wachs TD, Mccabe GP, Bassily NS, Bishry Z, Galal OM, Harrison GG \& Jerome NW (1991) Determinants of pregnancy outcome and newborn behavior of a semirural Egyptian population. American Journal of Clinical Nutrition 54, 657-667.

Kirksey A, Wachs TD, Yunis F, Srinath U, Rahmanifor A, Mccabe GP, Galal OM, Harrison GG \& Jerome NW (1994) Relation of maternal zinc nutriture to pregnancy outcome and infant development in an Egyptian village. American Journal of Clinical Nutrition 60, 782-792.

Lokken PM, Halas ES \& Sandstead HH (1973) Influence of zinc deficiency on behavior. Proceedings of the Society for Experimental Biology and Medicine 144, 680-682.

Merialdi M, Caulfield LE, Zavalet N, Figueroa A \& Di Pietro JA (1999) Adding zinc to prenatal iron and folate tablets improves fetal neurobehavioural development. American Journal of Obstetrics and Gynecology 180, 483-490.

Morley JE, Gordon J \& Hershman JM (1980) Zinc deficiency, chronic starvation, and hypothalamic-pituitarythyroid function. American Journal of Clinical Nutrition 33, 1767-1770.

Penland JG, Sandstead HH, Alcock NW, Dayal HH, Chen XC, Li JS, Shao F \& Yang JJ (1997) A preliminary report: effects of zinc and micronutrient repletion on growth and neuropsychological function of urban Chinese children. Journal of American College Health 16, 268-272.

Pfeiffer CC \& Braverman ER (1997) Zinc, the brain and behavior. Biology Psychology 17, 513-530.

Piaget J (1997) The Language and Thought of the Child. Cleveland, OH: World Publishing Company.

Ruff HA \& Rauthbart MK (1996) Attention in Early Development. New York, NY: Oxford University Press.

Sandstead HH, Fosmire GJ, McKenzie JM \& Halas ES (1975) Zinc deficiency and brain development in the rat. Federation Proceedings 34, 86-88.

Sandstead HH, Penland JG, Alcok NW, Dayal HH, Chen XC, Li JS, Zhao F \& Yang JJ (1998) Effects of repletion with zinc and other micronutrients on neuropsychologic performance and growth of Chinese children. American Journal of Clinical Nutrition 68 (Suppl.), 470S-475S.

Sandstead HH (1986) Nutrition and brain function: trace element. Nutritional Review 44, 37-41.

Sazawal S, Bentley M, Black RE, Dhingra P, George S \& Bhan MK (1996) Effect of zinc supplementation on observed activity in preschool children in an urban slum population. Pediatrics 98, 1132-1137.

Strobel DA \& Sandstead HH (1984) Social and learning changes following prenatal or postnatal zinc deprivation in rhesus monkey. In The Neurobiology of Zinc. Part B: Deficiency, Toxicity and Pathology, pp. 121-138 [CJ Frederickson, OA Howell and EJ Kasarskis, editors]. New York, NY: Alan R. Liss.

Wauben PM \& Wainwright PE (1999) The influence of neonatal nutrition on behavioral development: a critical appraisal. Nutrition Review 57, 35-44.

Wolke D, Skuse D \& Mathisen V (1990) Behavior style in failure to thrive infants: a preliminary communication. Journal of Pediatric Psychology 15, 237-254. 